\title{
PENERAPAN MODEL PEMBELAJARAN KOOPERATIF TIPE MAKE A MATCH UNTUK MENINGKATKAN HASIL BELAJAR PKn
}

\author{
Kasminah \\ Kasminah68@gmail.com \\ SD Negeri 003 Tasik Juang, Airmolek, Indonesia
}

\begin{abstract}
This research is motivated by the still low learning outcomes of PKn students in grade V SDN 003 Tasik Juang. This study aims to improve student PKn learning outcomes by applying a make a match cooperative model. The design of this research is classroom action research, which consists of two cycles. Each cycle consists of planning, implementing, observing, and reflecting. The results showed that, on the base score, of 30 students, the number of students who completed as many as 17 people while students who did not complete as many as 13 people. In the daily test I, the number of students who finished completed increased to 23 students and students who did not complete became 7 students. Cycle II the number of students who completed was 28 people while students who did not complete 2 people. The percentage of classical completeness in the base score of $56.6 \%$ then increased in the first cycle to $76.6 \%$ and then increased again in the second cycle to $93.3 \%$. Based on the results of the above research, it can be concluded that by applying the make a match type of cooperative learning model can improve the learning outcomes of PKn students in grade V Tasik Juang.
\end{abstract}

Keywords: cooperative learning model type make a match, Civics learning outcomes

\section{ABSTRAK}

Penelitian ini dilatarbelakangi oleh masih rendahnya hasil belajar PKn siswa kelas V SD Negeri 003 Tasik Juang. Penelitian ini bertujuan untuk meningkatkan hasil belajar PKn siswa dengan menerapkan model kooperatif tipe make a match. Desain penelitian ini adalah penelitian tindakan kelas (PTK), yang terdiri dari dua siklus. Setiap siklus terdiri dari perencanaan, pelaksanaa, pengamatan, dan refleksi. Hasil penelitian menunjukan bahwa, pada skor dasar, dari 30 orang siswa, jumlah siswa yang tuntas sebanyak 17 orang sedangkan siswa yang tidak tuntas sebanyak 13 orang. Pada ulangan harian I, jumlah siswa yang tuntas meningkat menjadi 23 orang siswa dan siswa yang tidak tuntas menjadi 7 orang siswa. Siklus II jumlah siswa yang tuntas adalah 28 orang sedangkan siswa yang tidak tuntas 2 orang. Persentase ketuntasan klasikal pada skor dasar sebesar 56.6\% selanjutnya meningkat pada siklus I menjadi $76.6 \%$ dan kemudian meningkat lagi pada siklus II menjadi $93.3 \%$. berdasarkan hasil penelitian di atas, dapat disimpulkan bahwa dengan menerapkan model pembelajaran kooperatif tipe make a match dapat meningkatkan hasil belajar PKn siswa kelas $\mathrm{V}$ Tasik Juang.

Kata Kunci: model pembelajaran kooperatif tipe make a match, hasil belajar PKn

\begin{tabular}{|c|c|c|}
\hline Submitted & Accepted & Published \\
\hline 15 Juli 2019 & 2 November 2019 & 12 November 2019 \\
\hline
\end{tabular}

\begin{tabular}{|l|c|c|c|c|}
\hline Citation & $:$ & $\begin{array}{c}\text { Kasminah. (2019). Penerapan Model Pembelajaran Kooperatif Tipe Make A Match untuk Meningkatkan Hasil Belajar } \\
\end{array}$ & $\begin{array}{l}\text { PKn. Jurnal PAJAR (Pendidikan dan Pengajaran), } \\
\text { http://dx.doi.org/10.33578/pjr.v3i6.7886. }\end{array}$ & 1264-1272. \\
\hline
\end{tabular}

\section{PENDAHULUAN}

Pada jenjang sekolah dasar, PKn mempunyai peranan penting untuk membentuk sikap dan karakter siswa dalam berperilaku, sehingga hendaknya setiap siswa mampu menjadi pribadi yang baik (Khaulani dkk, 2019). Maka dari itu, mata pelajaran PKn merupakan hal yang sangat mendasar yang harus dipelajari sebagai usaha penanaman moral pada siswa SD sejak dini. Untuk itu guru harus mampu mencari dan dapat membangun suasana belajar yang baik dan berkualitas agar siswa bisa tertarik dan senang untuk mengikuti proses pembelajaran PKn yang mana, muara akhir dari pembelajaran ini akan memberi dampak pada peningkatan hasil belajar PKn siswa.

Namun, berdasarkan pengalaman peneliti sendiri di SD Negeri 003 Tasik Juang, pembelajaran yang dilaksanakan masih kurang menarik perhatian siswa. Siswa masih asik dengan teman sebangkunya tanpa memperhatikan penjelasan dari guru. Walaupun guru telah menerapkan model atau pendekatan dalam 
pembelajaran, namun model atau pendekatan pembelajaran yang dilakukan guru belum sesui dengan materi sehingga kurang menarik bagi siswa. Lebih lanjut, permasalahan yang peneliti temukan sejalan dengan temuan yang di ungkap oleh Ratno (2018) yang menyatakan rendahnya kualitas dan hasil pembelajaran siswa disebabkan kurang tepatnya strategi atau pendekatan pembelajaran yang diterapkan dikelas atau pembelajaran yang terkesan monoton. Pendapat selanjutnya, Teladaningsih dkk (2019) mengungkapkan bahwa penyebab rendahnya proses dan hasil belajar disebabkan oleh guru masih cenderung mendominasi kegiatan pembelajaran, guru hanya sebatas menggunakan papan tulis tidak menggunakan media pembelajaran lainnya yang relevan untuk menunjang pembelajaran.

Dari berbagai permasalahan yang timbul di atas menyebabkna hasil belajar siswa kelas $\mathrm{V}$ SD Negeri 003 tasik Juang masih tergolong

\section{KAJIAN TEORETIS}

Model pembelajaran kooperatif tipe make a match ini dikembangkan oleh Lurna Curran pada tahun 1994 yang menyatakan siswa mencari pasangan sambil mempelajari suatu konsep atau topik tertentu dalam suasana yang menyenangkan. Biasa diterapkan untuk semua mata pelajaran dan tingkatan kelas (dalam Huda, 2011).

Menurut Rusman (2012) menyatakan langkah-langkah dari model pembelajaran kooperatif tipe make a match adalah sebagai berikut: 1) guru menyiapkan beberapa kartu yang berisi beberapa konsep/topik yang cocok untuk sesi review (satu sisi kartu berupa kartu soal dan sisi sebaliknya berupa kartu jawaban); 2) setiap siswa mendapat satu kartu dan memikirkan jawaban atau soal dari kartu yang dipegang; 3) siswa mempunyai pasangan yang mempunyai kartu yang cocok dengan kartunya (kartu soal/kartu jawaban); 4) siswa yang dapat mencocokkan kartunya sebelum batas waktu diberi poin; 5) setelah satu babak kartu dikocok lagi agar tiap siswa mendapat kartu yang berbeda dari sebelumnya, demikian seterusnya; 6) kesimpulan. rendah. Dimana, dari 30 orang siswa hanya 17 siswa atau $56.6 \%$ yang tuntas, sedangkan 13 orang siswa atau $43.4 \%$ belum tuntas. Siswa dikatakan tuntas apabila nilai siswa telah mencapai kriteria ketuntasan minimum sekolah yaitu sebesar 70 .

Berdasarkan uraian di atas, untuk meningkatkan hasil belajar siswa, maka peneliti mencoba menerapkan model Pembelajaran yang lebih tepat dengan pembelajaran salah satunya adalah model kooperatif tipe make a match. Model pembelajaran kooperatif tipe make a match ini yaitu model pembelajaran yang dimulai dengan teknik, yaitu siswa disuruh mencari pasangan kartu yang merupakan jawaban/ soal sebelum batas waktunya, siswa yang dapat mencocokkan kartunya diberi poin (Rusman, 2012). Dengan berprinsip kepada belajar sambil bermain, maka diharapkan dengan menerapkan model ini dapat meningkatkan hasil belajar PKn siswa.

Di samping itu model pembelajaran kooperatif tipe make a match juga memiliki kelebihan dan kekurangan seperti dijelaskan dalam Istarani (2011). Kelebihan dari model pembelajaran kooperatif tipe make a match antara lain: 1) siswa terlibat langsung dalam menjawab soal yang disampaikan kepadanya melalui kartu; 2) menghindari kejenuhan siswa dalam mengikuti proses belajar mengajar; 3) meningkatkan kreativitas belajar siswa; 3) dapat menumbuhkan kreativitas berpikir siswa, sebab melalui pencocokkan pertanyaan dan jawaban akan tumbuh tersendirinya; 4) pembelajaran lebih menyenangkan karena melibatkan media pembelajaran yang digunakan guru.

Sementara kekurangan dari model pembelajaran kooperatif tipe make a match adalah sebagai berikut : 1) sulit bagi guru untuk mempersiapkan kartu-kartu yang baik dan bagus; 2) slit mengatur ritme atau jalannya proses pembelajaran; 3) siswa kurang menyerapi makna pembelajaran yang ingin disampaikan karena siswa merasa hanya sekedar permainan saja; 4) sulit untuk mengonsentrasikan anak. 


\section{METODE PENELITIAN}

Penelitian ini dilakukan di SD Negeri 003 Tasik Juang dengan subjek penelitian adalah siswa kelas $\mathrm{V}$ yang berjumlah sebanyak 30 orang siswa yang memiliki kemampuan berbeda-beda. Tujuan dilakukan penelitian ini adalah untuk meningkatkan hasil belajar PKn siswa kelas V SD Negeri 003 Tasik Juang.

Desain penelitian ini adalah penelitian tindakan kelas (PTK), yaitu suatu pencermatan terhadap kegiatan belajar berupa sebuah tindakan, yang sengaja dimunculkan dan terjadi dalam sebuah kelas secara bersama (Arikunto, 2008). Tindakan yang dilakukan dalam penelitian ini adalah menerapkan Model pembelajaran kooperatif tipe make a match. Pelaksanaan penelitian ini terdiri dari dua siklus. Setiap siklus terdiri dari perencanaan, pelaksanaa, pengamatan, dan refleksi. Adapun uraiannya dapat dilihat sebagai berikut:

1. Perencanaan

Perencanaan penelitian tindakan kelas (PTK), berisikan kegiatan yang akan dilakukan untuk memperbaiki, meningkatkan atau perubahan tingkah laku dan sikap sebagai solusi. Perencanaan ini dimulai dengan menetapkan kelas sebagai tempat penelitian yaitu SD Negeri 003 Tasik Juang. Menetapkan jadwal penelitian, menyiapkan perangkat pembelajaran seperti silabus, rencana pelaksanaan pembelajaran (RPP), lembar kerja siswa, evaluasi, ulangan harian, dan lembar observasi guru dan siswa.

2. Pelaksanaan

Penerapan dari perencanaan yang telah dibuat yaitu dengan memberikan motivasi siswa dalam melakukan pembelajaran melalui penerapan model pembelajaran kooperatif tipe make a match.

\section{Pengamatan}

Dilakukan bersamaan dengan pelaksanaan tindakan dengan melibatkan seorang observer yaitu teman sejawat yang menggunakan lembar observasi untuk mengamati kegiatan guru dan siswa.

4. Refleksi

Peneliti mengkaji, melihat dan mempertimbangkan atas hasil atau dampak dari tindakan dari berbagai kriteria. Tujuannya adalah mengetahui kekuatan dan kelemahan dari tindakan yang dilakukan untuk dapat diperbaiki pada siklus berikutnya.

\section{Teknik Pengumpulan Data \\ Teknik Pengamatan}

Teknik pengamatan ini menggunakan lembar pengamatan yang dilakukan peneliti untuk mengamati seluruh kegiatan yang berlangsung dari aktivitas guru dan siswa, mulai dari awal pembelajaran sampai proses pembelajaran berakhir.

\section{Teknik Tes}

Teknik tes yang digunakan dalam penelitian ini adalah tes tertulis, tes tertulis bertujuan untuk mengetahui peningkatan hasil belajar siswa mengenai materi yang belum dipahami berupa soal-soal yang harus dijawab. Pemberian tes hasil belajar ini dilakukan setelah pembelajaran melalui penerapan model pembelajaran kooperatif tipe make a match ini berakhir.

\section{Teknik Analisis Data}

Teknik analisis data ini dilakukan dengan teknik analisis deskriptif. Tujuan dari analisis deskriptif adalah untuk mendeskripsikan hasil belajar siswa setelah penerapan model pembelajaran kooperatif tipe make a match. Analisis data berguna untuk melihat peningkatan aktivitas guru dan siswa setelah penerapan model pembelajaran kooperatif tipe make a match.

\section{Aktivitas Guru dan Siswa}

Observasi aktivitas guru dan siswa dilakukan bersamaan dengan pelaksanaan kegiatan pembelajaran dan dilakukan oleh observer. Analisis data aktivitas guru dan siswa selama kegiatan mengajar dapat ditentukan dengan rumus:

$\mathrm{P}=\frac{F}{N} \times 100 \%($ Dirto, 2016)

Keterangan :

$\mathrm{P}=$ Persentase Rata-rata aktivitas guru

$\mathrm{F}=$ Jumlah skor aktivitas guru yang diperoleh

$\mathrm{N}=$ Skor Maksimal yang didapat dari aktivitas guru 
Tabel 1. Interval dan Kategori Aktivitas Guru dan Siswa

\begin{tabular}{ll}
\hline$\%$ Interval & Kategori \\
\hline $81-100$ & Amat baik \\
$61-80$ & Baik \\
$51-60$ & Cukup \\
Kurang dari 50 & Kurang \\
\hline
\end{tabular}

(Riduan, 2008)

\section{Analisis Hasil Belajar}

Analisis data tentang peningkatan hasil belajar PKn siswa kelas V SD Negeri 003 Tasik Juang. Ada dua kategori dalam analisis belajar, yaitu ketuntasan individu dan ketuntasan klasikal.

1. Ketuntasan individu

Setiap siswa dapat dikatakan tuntas belajar jika nilai siswa tersebut telah mencapai Kriteria Ketuntasan Minimal (KKM) yang telah ditetapkan sekolah yaitu 70. Ketuntasan belajar individu dihitung dengan Rumus sebagai berikut

$\mathrm{KI}=\frac{S P}{S M} x 100($ adaptasi dari Ratno, 2018)

Keterangan :

$\mathrm{KI}=$ Ketuntasan individu

$\mathrm{SP}=$ Skor yang diperoleh siswa

$\mathrm{SM}=$ Skor maksimal

Dengan kriteria apabila seorang siswa (individu) telah mencapai nilai $\geq 70$ dari soal yang diberikan maka individu dikatakan tuntas.

\section{HASIL DAN PEMBAHASAN}

Penelitian tindakan kelas ini dilakukan sebanyak dua siklus. Satu siklus terdiri dari 3 kali pertemuan, dua kali pembahasan materi pembelajaran dan satu kali ulangan harian. Tindakan yang dilakukan dalam penelitian ini adalah melaksanakan pembelajaran dengan menerapkan model pembelajaran kooperatif tipe make a match untuk meningkatkan hasil belajar siswa kelas V SD Negeri Tasik Juang. Berikut
Begitu juga sebaliknya apabila nilai siswa di bawah 70 itu artinya siswa tersebut tidak tuntas.

2. Ketuntasan klasikal

Untuk mengetahui ketuntasan klasikal, dapat dilakukan dengan cara membandingkan jumlah siswa yang mencapai KKM dengan jumlah semua siswa kemudian dikalikan 100. Adapun rumus yang digunakan untuk menentukan klasikal adalah :

$\mathrm{KK}=\frac{J S T}{J S} x 100 \% \quad($ Kusnidar, 2016)

Keterangan:

$\mathrm{KK}=$ Ketuntasan klasikal

$\mathrm{JT}=$ Jumlah siswa yang tuntas

$\mathrm{JS}=$ Jumlah siswa seluruhnya.

Dengan kriteria apabila suatu kelas telah mencapai $75 \%$ dari jumlah siswa yang tuntas maka kelas itu dinyatakan tuntas jika belum tuntas diadakan Remedial.

hasil observasi aktivitas guru dan siswa siklus I dan siklus II.

Aktivitas Guru

Aktivitas guru dalam proses pembelajaran dihitung berdasarkan lembar observasi aktivitas guru selama proses pembelajaran berlangsung. Hasil analisis aktivitas guru dapat dilihat pada tabel di bawah ini : 
Tabel 2. Peningkatan Aktivitas Guru Siklus I dan Siklus II

\begin{tabular}{llcccc}
\hline No & Uraian & \multicolumn{2}{c}{ Siklus I } & \multicolumn{2}{c}{ Siklus II } \\
\cline { 2 - 6 } & & P1 & P2 & P3 & P4 \\
\hline 1 & Jumlah & 12 & 15 & 16 & 18 \\
2 & Persentase & $60 \%$ & $75 \%$ & $80 \%$ & $90 \%$ \\
3 & Kategori & Cukup & Baik & Baik & Amat baik \\
\hline
\end{tabular}

Berdasarkan hasil analisis data pada tabel di atas, terlihat aktivitas guru terus meningkat dari pertemuan pertama siklus I sampai pertemuan keempat siklus II. Pada siklus I pertemuan pertama persentase sebesar $60 \%$ dengan kategori cukup, pertemuan kedua persentasenya sebesar $75 \%$ dengan kategori baik. Siklus II pertemuan ketiga persentase sebesar $80 \%$ dengan kategori baik dan pertemuan keempat persentase sebesar $90 \%$ dengan kategori amat baik.

Peningkatan yang terjadi disebabkan karena kekurangan-kekurangan yang dijumpai dalam proses pembelajaran seperti: penguasaan kelas, penerapan make a match, kurang memberikan penjelasan tentang bermain kartu sesuai langkah-langkah make a match, tidak mengajak siswa secara keseluruhan dalam menyimpulkan materi pembelajaran di kelas dapat di atasi dengan baik oleh guru. Artinya tindakan yang diberikan guru pada siklus II berdampak lebih baik daripada tindakan pada siklus I. hal ini memberikan gambaran bahwa model pembelajaran kooperatif tipe make a match dengan siswa sebagai pusat pembelajaran dan dibimbing guru secara menyenangkan dapat meningkatkan hasil belajar siswa.

\section{Aktivitas Siswa}

Aktivitas siswa dalam proses pembelajaran dianalisis berdasarkan lembar observasi aktivitas siswa. Adapun hasil analisis aktivitas siswa dapat dilihat pada tabel di bawah ini :

Tabel 2. Peningkatan Aktivitas Guru Siklus I dan Siklus II

\begin{tabular}{llcccc}
\hline No & Uraian & \multicolumn{2}{c}{ Siklus I } & \multicolumn{2}{c}{ Siklus II } \\
\cline { 3 - 6 } & & P1 & P2 & P1 & P2 \\
\hline 1 & Jumlah & 11 & 16 & 17 & 18 \\
2 & Persentase & $55 \%$ & $80 \%$ & $85 \%$ & $95 \%$ \\
3 & Kategori & Cukup & Baik & Amat Baik & Amat baik \\
\hline
\end{tabular}

Berdasarkan hasil analisis data pada tabel di atas, terlihat aktivitas siswa terus meningkat dari pertemuan pertama siklus I sampai pertemuan keempat siklus II. Pada siklus I pertemuan pertama persentasenya sebesar $55 \%$ dengan kategori cukup, pertemuan kedua persentasenya sebesar $80 \%$ dengan kategori baik. Siklus II pertemuan ketiga persentasenya sebesar $85 \%$ dengan kategori amat baik dan pertemuan keempat persentasenya sebesar $95 \%$ dengan kategori amat baik.

Peningkatan aktivitas siswa terjadi karena, sewaktu guru menyampaikan tujuan dan motivasi di kelas, siswa terlihat antusias untuk mendengarkan guru dengan baik. Selain itu, sewaktu guru menyampaikan materi, siswa juga terlihat aktif dan berlomba untuk maju kedepan dan pada pase terakhir yaitu evaluasi, tampak siswa mengerjakan dengan semangat. Dengan ini dapat di simpukan pembelajaran kooperatif tipe make a match dapat meningkatkan aktivitas dan motivasi belajar siswa.

\section{Hasil belajar PKn}

Ketuntasan individu dan klasikal

Analisis hasil belajar PKn pada siklus I dan siklus II dalam penelitian ini dianalisis dengan melihat ketuntasan individu dan klasikal belajar siswa yang mencapai KKM sesuai 
dengan yang ditetapkan sekolah yaitu 70 . Ketuntasan hasil belajar siswa dari ulangan harian I dan ulangan harian II mengalami peningkatan. Untuk melihat peningkatan hasil belajar siswa setelah menerapkan model pembelajaran kooperatif tipe make a match dapat dilihat pada tabel berikut :

Tabel 3. Ketuntasan Belajar PKn Pada Penerapan Model Pembelajaran Kooperatif Tipe Make a Match pada Siklus I dan II

\begin{tabular}{cccccc}
\hline \multirow{2}{*}{ Siklus } & \multirow{2}{*}{ Jumlah siswa } & \multicolumn{2}{c}{ Ketuntasan invividu } & \multicolumn{2}{c}{ Ketuntasan klasikal } \\
\cline { 3 - 6 } & & $\begin{array}{c}\text { Jumlah siswa } \\
\text { tuntas }\end{array}$ & $\begin{array}{c}\text { Jumlah siswa } \\
\text { tidak tuntas }\end{array}$ & $\begin{array}{c}\text { Persentase } \\
\text { ketuntasan }\end{array}$ & Kategori \\
\hline Skor dasar & 30 & 17 & 13 & $56.6 \%$ & TT \\
UH I & 30 & 23 & 7 & $76.6 \%$ & T \\
UH II & 30 & 28 & 2 & $93.3 \%$ & T \\
\hline
\end{tabular}

Keterangan :

$\mathrm{T}=$ Tuntas

TT= Tidak Tuntas

Berdasarkan tabel di atas dapat dilihat bahwa setelah penerapan model pembelajaran kooperatif tipe make a match, ketuntasan individu dan klasikal mengalami peningkatan pada setiap siklusnya. Pada skor dasar, dari 30 orang siswa, jumlah siswa yang tuntas sebanyak 17 orang sedangkan siswa yang tidak tuntas sebanyak 13 orang. Pada ulangan harian I, jumlah siswa yang tuntas meningkat menjadi 23 orang siswa dan siswa yang tidak tuntas menjadi 7 orang siswa. Siklus II jumlah siswa yang tuntas adalah 28 orang sedangkan siswa yang tidak tuntas 2 orang. Persentase ketuntasan klasikal pada skor dasar sebesar $56.6 \%$ selanjutnya meningkat pada siklus I menjadi $76.6 \%$ dan kemudian meningkat lagi pada siklus II menjadi $93.3 \%$. Berdasarkan hasil penelitian yang telah dilaksanakan bahwa dengan penerapan model pembelajaran kooperatif tipe make a match pada mata pelajaran PKn dapat meningkatkan hasil belajar siswa di kelas V SD Negeri 003 Tasik Juang.
Sejalan dengan hasil penelitian di atas, Nursian (2019) menyatakan bahwa model pembelajaran make a match mampu membuat siswa memahami materi pelajaran dengan cepat, serta siswa juga dapat untuk saling menghormati pendapat rekan yang membacakan soal atau jawaban di depan kelas. lebih lanjut, Sutini (2018) menyatakan dengan menggunakan model pembelajaran make a match mampu membuat siswa menjadi semangat dan mnghilangkan kejenuhan dalam pembelajaran berlangsung sehingga berimbas pada peningkatan hasil belajar siswa.

\section{Penghargaan kelompok}

Nilai perkembangan individu dihitung berdasarkan nilai yang diperoleh pada ujian akhir siklus dibanding dengan skor sebelumnya. Kemudian nilai perkembangan kelompok dibagi jumlah anggota kelompok sehingga diperoleh rata-rata nilai perkembangan. Nilai perkembangan dan penghargaan kelompok pada siklus I dan siklus II dapat dilihat pada tabel di bawah ini :

Tabel 4. Nilai Perkembangan dan Penghargaan Kelompok Pada Siklus I dan Siklus II

\begin{tabular}{cccccc}
\hline Penghargaan & \multicolumn{3}{c}{ Siklus I } & \multicolumn{2}{c}{ Siklus II } \\
\cline { 2 - 5 } & P1 & P2 & P3 & P4 \\
\hline Baik & 5 & 1 & - & - \\
Hebat & 1 & 4 & 4 & 3 \\
Super & - & 1 & 2 & 3 \\
\hline
\end{tabular}


Dari tabel di atas dapat dilihat bahwa pada siklus I pertemuan pertama, terdapat 5 kelompok dengan predikat baik dan 1 kelompok dengan predikat hebat. Pertemuan kedua meningkat menjadi 1 kelompok dengan predikat baik, 4 kelompok dengan predikat hebat, dan 1 kelompok dengan predikat super. Pada siklus II pertemuan ketiga ada 4 kelompok dengan predikat hebat dan 2 kelompok dengan predikat super. Pertemuan keempat siklus II meningkat lagi menjadi 3 kelompok dengan predikat hebat dan 3 kelompok dengan predikat super. Ini berarti proses kerjasama antar kelompok dalam pembelajaran kooperatif tipe make a match pada penelitian ini mengalami perkembangan sangat baik.

\section{Pembahasan}

Berdasarkan hasil penelitian yang telah dilaksanakan bahwa dengan penerapan model pembelajaran kooperatif tipe make a match pada mata pelajaran PKn siswa kelas V SD Negeri 003 Tasik Juang dapat meningkatkan aktivitas guru dan siswa. hal ini dapat diketahui pada siklus I persentase rata-rata aktivitas guru pertemuan pertama adalah $75 \%$ dengan kategori baik meningkat menjadi 90\% dengan kategori sangat baik pada siklus II. Dari data tersebut dapat dilihat bahwa peningkatan persentase ratarata adalah $15 \%$.

\section{SIMPULAN DAN REKOMENDASI}

Berdasarkan hasil penelitian di atas maka dapat disimpulkan bahwa dengan menerapkan model pembelajaran kooperatif tipe make a match dapat meningkatkan hasil belajar PKn siswa kelas V Tasik Juang. Peningkatan hasil penelitian dapat kita lihat sebagai berikut:

1. Aktivitas guru, pada siklus I pertemuan pertama persentasenya sebesar $60 \%$ dengan kategori cukup, pertemuan kedua persentasenya sebesar $75 \%$ dengan kategori baik. Siklus II pertemuan ketiga persentasenya sebesar $80 \%$ dengan kategori baik dan pertemuan keempat persentasenya sebesar 90\% dengan kategori amat baik.

2. Aktivitas siswa, Pada siklus I pertemuan
Peningkatan aktivitas siswa dapat dilihat dari siklus I dengan persentase rata-rata $80 \%$ dengan kategori baik dan meningkat menjadi 95\% pada siklus I dengan kategori sangat baik. Dari siklus I ke siklus II berarti terjadi peningkatan persentase aktivitas siswa menjadi $15 \%$.

Dari analisis hasil belajar siswa diperoleh fakta bahwa terjadi peningkatan hasil belajar PKn siswa dari skor dasar ke siklus I meningkat sebesar $20 \%$ dan dari siklus I ke siklus II meningkat sebesar $16.7 \%$.

Ketuntasan individu dan klasikal juga mengalami peningkatan. Hal ini dapat dilihat pada skor dasar, dengan jumlah siswa 30 orang, siswa yang tuntas sebanyak 17 orang $(56.6 \%)$ kemudian meningkat pada siklus I siswa yang tuntas menjadi $23(76.6 \%)$ orang dan siswa yang tidak tuntas sebanyak 7 orang. Selanjutnya meningkat lagi menjadi 28 orang (93.3\%) pada siklus II.

Peningkatan hasil penelitian di atas terjadi karena model pembelajaran kooperatif tipe make a match mampu membantu siswa mengembangkan kemampuannya baik secara kognitif maupun afektif. Selain itu model pembelajaran ini membuat pembelajaran menyenangkan, sehingga dapat meningkatkan motivasi belajar siswa dan mampu menanamkan kedisiplinan dalam belajar (Huda, 2012).

pertama persentase sebesar $55 \%$ dengan kategori cukup, pertemuan kedua persentase sebesar $80 \%$ dengan kategori baik. Siklus II pertemuan ketiga persentase sebesar $85 \%$ dengan kategori amat baik dan pertemuan keempat persentasenya sebesar $95 \%$ dengan kategori amat baik.

3. Hasil belajar PKn siswa, pada skor dasar, dari 30 orang siswa, jumlah siswa yang tuntas sebanyak 17 orang sedangkan siswa yang tidak tuntas sebanyak 13 orang. Pada ulangan harian I, jumlah siswa yang tuntas meningkat menjadi 23 orang siswa dan siswa yang tidak tuntas menjadi 7 orang siswa. Siklus II jumlah siswa yang tuntas adalah 28 orang 
sedangkan siswa yang tidak tuntas 2 orang. Persentase ketuntasan klasikal pada skor dasar sebesar $56.6 \%$ selanjutnya meningkat pada siklus I menjadi $76.6 \%$ dan kemudian meningkat lagi pada siklus II menjadi $93.3 \%$

4. Penghargaan kelompok, pada siklus I pertemuan pertama, terdapat 5 kelompok dengan predikat baik dan 1 kelompok dengan predikat hebat. Pertemuan kedua meningkat menjadi 1 kelompok dengan predikat baik, 4 kelompok dengan predikat hebat, dan 1 kelompok dengan predikat super. Pada siklus II pertemuan ketiga ada 4 kelompok dengan predikat hebat dan 2 kelompok dengan predikat super

Berdasarkan simpulan dalam penelitian

\section{DAFTAR PUSTAKA}

Arikunto, S. (2008). Penelitian Tindakan Kelas. Jakarta: Bumi Aksara.

Dirto. (2016). Penerapan Pendekatan Contextual Teaching and Learning untuk Meningkatkan Hasil Belajar PPKN Siswa Kelas VI SD Negeri 014 Beringin Makmur Kecamatan Kerumutan. Primary: Jurnal Program Studi Pendidikan Guru Sekolah Dasar, 5(2), 354-356.

Depdiknas. (2003). Undang-Undang RI No.20 Tahun 2003. Tentang Sistem Pendidikan Nasional.

Huda, M. (2011). Cooperative learning. Jogyakarta : Pustaka Belajar.

Huda, M. (2012). Cooperative Learning Metode, Teknik, Struktur dan. Model Terapan. Yogyakarta: Pustaka Pelajar.

Istarani. (2011). 58 Model Pembelajaran Inovatif. Medan: Kepala Balai Diklat Keagamaan.

Kaulani, F., \& Noviana, E. 2019. Penerapan Metode Brainstorming Dengan Bantuan Media Gambar Grafis Untuk Meningkatkan Hasil Belajar Pkn Siswa Kelas V SD Negeri 009 Pulau Kecamatan Bangkinang Kabupaten Kampar. Jurnal PAJAR (Pendidik dan Pengajar), 3 (2), 1825.

Kusnidar, D. (2016). Upaya Meningkatkan Hasil Belajar Ilmu Pengetahuan Alam Dengan yang telah dilakukan, maka peneliti mengajukan beberapa rekomendasi sebagai berikut : 1) model pembelajaran kooperatif tipe make a match dapat dijadikan salah satu pemecah masalah dalam pembelajaran karena memberikan banyak dampak positif yang dapat meningkatkan hasil belajar. Hal ini juga disebabkan karena model pembelajaran ini merupakan model pembelajaran yang menyenangkan, melatih anak untuk aktif, berani dan meningkatkan rasa menghargai orang lain. 2) Sebaiknya dalam menerapkan model pembelajaran kooperatif tipe make a match agar lebih mengefisienkan waktu dalam proses pembelajaran terutama saat melakukan permainan kartu dan pembagian kelompok.

Penerapan Metode Demonstrasi Siswa Kelas IV SD Negeri 010 Banjar Panjang Kecamatan Kerumutan. Primary: Jurnal Program Studi Pendidikan Guru Sekolah Dasar, 5(3), 307-316.

Nursian. (2019). Adaptasi Model Pembelajaran Make A Match dengan Talking Stick untuk Meningkatkan Hasil Belajar IPS Siswa Kelas VIII SMP Negeri 15 Dumai. Jurnal PAJAR (Pendidikan dan Pengajaran), 3(2), 248-257. DOI: http://dx.doi.org/10.33578/pjr.v3i2.6855.

Ratno. (2018). Penerapan Model Pembelajaran Kooperatif Tipe Make A Match untuk Meningkatkan Hasil Belajar Pendidikan Agama Budha Siswa Kelas IV SDN 003 Tembilahan Kota. Jurnal PAJAR (Pendidikan dan Pengajaran), 3 (2), 311316.

Rusman. (2012). Model-model Pembelajaran. Bandung : Raja Prasindo Persada.

Rusman. (2012). Model-model Pembelajaran. Bandung : Raja Prasindo Persada.

Riduwan. (2008). Belajar Mudah Penelitian untuk Guru-Karyawan dan Peneliti Pemula. Bandung: Alfabeta.

Sutini. (2018). Model Pembelajaran Kooperatif Tipe Make A Match untuk Meningkatkan Hasil Belajar IPA Siswa Kelas IV SDN 016 Beringin Jaya Kecamatan Singingi 
Jurnal PAJAR (Pendidikan dan Pengajaran)

Volume 3 Nomor 6 November 2019 | ISSN Cetak : 2580 - 8435 | ISSN Online : 2614 - 1337

DOI : http://dx.doi.org/10.33578/pjr.v3i6.7886

Hilir Kabupaten Kuantan Singingi. Jurnal

PAJAR (Pendidikan dan Pengajaran), 2(5), 704-710.

Teladaningsih,O., Mawardi., \& Huliana, I. (2019). Implementasi Model Pembelajaran Teams Games Tournament Meningkatkan
Keterampilan Kolaboratif Peserta Didik Kelas 4 SD. Pendas : Jurnal Ilmiah Pendidikan Dasar, IV(1), 17-30. 